\title{
The Dilemma of the Energy Law and Policy Triangle in Recent Energy Laws and Policies in Bangladesh
}

Md. Raisul Islam Sourav

\begin{abstract}
The energy law and policy triangle are a complex area where energy law and policy are situated at the centre of a triangle and three other inalienable horns relating to this i.e. energy supply and energy security, cost relating to production of energy and environmental protection and preservation equally pull energy law and policy towards their direction. However, the energy law and policy emerge as a concern all over the world and states are taking initiative to ensure a balance among these three dilemmas. It is the reality that Bangladesh suffers severe shortage in power generation which also affects its overall economic development. Hence, in one hand, it needs to ensure continuous energy supply which is closely connected with country's energy security also. On the other hand, it also needs to make a balance between the challenges of producing energy in affordable cost which will not adversely affect the environment as well. Nevertheless, Bangladesh, being a lower-middle income country at least put focus on the energy law and policy triangle in recent years. Still ensuring balance among these threeopposite directions is still a challenge for Bangladesh. Despite that, the recent laws and policies relating to energy in Bangladesh show its commitment towards climate change mitigation which encourages more production and use of renewable energies in the country. Although there are some deficiencies in those laws and policies which can be overcome by further initiative. The State can reaffirm its position towards environmentally friendly affordable energy by amending those policies and legislations. This research paper is aimed to assess the dilemma of the Energy Law and Policy Triangle in recently legislated energy related laws and policies in Bangladesh.
\end{abstract}

Keywords: Energy law and policy triangle, energy, renewable, law, Bangladesh

\section{Introduction}

Tnergy law is one of the complex areas of law which Einvolves with other disciplines to some extent and is concerned with a variety of issues like climate change, environmental law, food and agricultural law, water law, hazardous waste management, natural resources, sustainability, environmental justice, environmental economics, dispute resolution etc $^{1}$. However, energy law and policy mainly deals with proper management of energy resources ${ }^{2}$. In the modern world, energy emerges as crucial issue due to heavy demand to ensure development all over the globe. Although there were laws in the 18th century to deal with energy sources like coal and oil, popularly known as fossil fuels but the issue attracted more concentration after the Second World War (1945) when the globe became conscious about low-carbon energy sources consist of nuclear energy, hydropower, biomass, wind turbines, solar, geothermal and other forms of renewable energy sources which are also regarded of as clean energy ${ }^{3}$.

Energy law and policy are highly entangled in many ways and significant to maintain a balance among environmental issues, sustainable development, economic growth etc. Energy policy denotes issues relating to energy development including energy production, distribution and consumption. However, a fit for purpose energy policy develops by a combination mixture of a clear long-term vision, political consensus, stable institutions, leadership, stakeholders' engagement etc $^{4}$. Now-a-days, the world's commitment to reduce $\mathrm{CO} 2$ emissions and emphasize on use of clean sources of energy creates a triangle in the energy sector which is termed the Energy Law and Policy Triangle in this arena.
The energy law and policy triangle symbolizes a dilemma where energy law and policy is in the center of a triangle and economics (finance), politics (energy security) and environment (climate change mitigation) are situated in the opposite angles and each trying to pull energy law and policy in their direction equally ${ }^{5}$.

Nevertheless, whilst some authors suggest the use of the terminology "Energy Trilemma" and interchanged the word with the energy triangle, there is a thin distinction between these two $^{6}$. The energy trilemma focuses on three core dimensions, namely: energy security, energy equity and environmental sustainability whereas energy triangle broadly emphasizes financial issues relating to energy matters in addition to these. On the contrary, the economics issue is neglected in the concept of trilemma. Effective and efficient energy law and policy of a country can ensure balance among these three-dichotomous forces to deliver better outcome to the society.

The word "energy" has wide dimension and defined in various ways in Bangladesh according to the purpose of different legislations. Hence, this essay will mainly confine in electricity while referring the term energy subsequently and to some extent gas and petroleum substance which are also recognized as energy under the Energy Regulatory Commission Act, 2003 of Bangladesh $^{8}$. However, there are a number of legislations and policies which are dealing with energy issues in Bangladesh like the Nation Energy Policy; the Renewable Energy Policy; the Nuclear Power Plant Act, 2015; The Atomic Energy Control Act, 2012; the Electricity Act, 2012 etc. The subsequent discussion will be confined in the recently enacted legislatures and policies governing 
energy triangle in Bangladesh. However, the main focus of this article is to critically evaluate how the energy laws and policies of Bangladesh are dealing with the concept of the energy law and policy triangle.

\section{Energy Triangle in Bangladesh}

Bangladesh has been maintaining hearty growth over the last couple of decades. However, the present government is committed to bump up the country to the status of a middle-income country by 2021 and a developed country by $2041^{9}$. This vision to be turned into truth, a massive continuous supply of energy in the form of electricity will be required in a secured and affordable manner.

Nevertheless, Bangladesh being a lower middleincome country is struggling to balance the energy triangle as these three horns have repulsion against each other and that is why balancing them is quite challenging ${ }^{10}$. According to International Energy Agency (IEA), the concept of security of energy supply or energy security mean the incessant availability of energy resources at an affordable cost. Although it is a naturally resourceful country considering natural gas and coal specially but due to lack of adequate technical expertise it cannot utilize its resources in generating energy. That is why it is highly dependent on fuel importation from overseas. Nonetheless, energy security is entwined with national security also ${ }^{11}$. National security may be compromised for disrupted supply of energy. It may bring heavy consequence for Bangladeshi national security. Therefore, conservation of national energy resources and sustainable use of them is essential to diminish the national security dilemma ${ }^{12}$.

However, accessible energy is a potential tool to empower mass people. Here comes the question of universal access to energy. According to the World Bank data, more than one-third populace of the country have no access to electricity yet. One the contrary, demand is escalating everyday while supply is not uninterrupted due to many factors including shortage of fuel, power scarcity, old supply line etc. Although situation is far more better now because of the initiatives taken by the current government ${ }^{13}$.

Then the question of economics will come to intervene then. The government has frequently increased the price of basic household energy like gas and electricity last couple of years even in contravention of law which ultimately diminish the affordability and accessibility as well. For this reason, despite of having power supply, marginal people are becoming unable to afford that costly energy for their livelihood. This is another challenge for Bangladesh to make energy affordable to all. Accountable and transparent government machineries relating to power sector and effective energy regulatory commission can play vital role to reduce the charge over energy ${ }^{14}$.

\section{The National Energy Policy of Bangladesh}

In recent few years, present government of Bangladesh took massive drive to produce energy for the country ${ }^{15}$. Millions of people get electricity in rural area. Despite that, in Bangladesh the demand of energy is rising every day. Demand is higher than the production, transmission \& distribution capability. Especially power demand exceeds generation capacity ${ }^{16}$. There are also some tailbacks in power transmission and distribution system. All these leads to increased load shed and poor quality of power supply ${ }^{17}$.

The National Energy Policy (NEP) first appeared in 1995 for overall management of energy in the country ${ }^{18}$. Subsequently it amended and present NEP came in 2004 under the supervision of Ministry of Power, Energy and Natural Resources which was updated subsequently in November 2005. However, the background of the policy justifies the necessity of introducing a new NEP which says $^{19}$ :

"Improving access to energy in Bangladesh is a fundamental contribution to poverty reduction and key to attaining the United Nations Millennium Development Goals. As energy is prerequisite for social and economic development, it is essential to move towards sustainability in energy systems both in order to protect natural life-support systems on which humanity depends, and to eradicate poverty."

The statement can boldly clarify the aims and purposes of the NEP and balancing the energy law and policy triangle efficiently. It emphasizes on rationale use of energy sources to meet the growing demand on a sustainable basis. It also focused on renewable energy to meet the future challenges. However, it does not give any guideline towards energy security. Still energy production is mostly dependent on indigenous sources like gas and coal. Ninety percent of country's total energies are being produced by gas, as of June 2009 the estimated proven recoverable reserve from 23 gas fields were 15.10 TSCF, of which total 8.40 TSCF gas has been already produced leaving only $6.71 \mathrm{TSCF}$ of recoverable category ${ }^{20}$. Hence, the reserve is diminishing gradually and the question of energy security becomes vulnerable day by day.

The Haripur oil deposits is the only so far discovered in the country which produced a total of about 650,000 bbls of crude oil till $1994^{21}$. However, the oil production has been ceased because of reduction of pressure and influx of water in the oil zone. Hence, the country is highly dependable on overseas oil exportation which also makes threats to energy security. However, the NEP suggests comprehensive exploration efforts need to be mounted in this field for further extraction of oil. Moreover, efforts are required to be given to exploration of the anticipated liquid Hydrocarbon prospects deeper to the sub-surface high pressure zone, which has not yet 
been penetrated.

Biomass fuels play an important role (about $65 \%$ of primary energy) in meeting total energy need of the country $^{22}$. But they are now being consumed beyond their regenerative limits. Unplanned and uncontrolled use of biomass fuels is causing environmental degradation ${ }^{23}$.

\section{The Renewable Energy Policy of Bangladesh}

In last few decades, Bangladesh was highly dependent on imported indigenous sources to produce electricity in country. However, the reserves of indigenous sources are decreasing and not viable for sustainable development. Hence, Bangladesh has shifted its focus from indigenous sources of energy to renewables and adopted a Renewable Energy Policy (REP) in 2008 to speed up the use of renewable in generating energies ${ }^{24}$. Gradual declination of availability of fossil fuels and resultant price volatility due to demand supply gap, considering the energy security and global concern about $\mathrm{CO} 2$ emissions push Bangladesh to adopt an environmentally friendly sustainable policy in energy sector and the REP is the outcome of that.

In addition, the Constitution of the People's Republic of Bangladesh put an obligation on the State to remove the disparity in the standards of living between the urban and rural areas and the government tries to obtain the goal through rural electrification and development ${ }^{25}$. Although investment costs of renewables are generally higher compared to fossil fuel alternatives, this option becomes economically viable when all externalities (e.g. environmental cost, health hazards etc.) and lower operating cost are taken into consideration ${ }^{26}$.

Solar, wind, biomass, biogas, bio-fuels, hydro, geothermal, river current, wave and tidal energy etc are the major renewable energy sources of the country. Solar photovoltaic (PV) systems are in use throughout the country with over 300,000 household-level installations having capacity of about 15 MW (November 2008). ${ }^{27}$ Wind Energy has also made some inroads although its prospect is mainly in marine areas, and offshore islands with strong wind regimes. Furthermore, Bangladesh has strong potential for biomass gasification based electricity. Many common biomass resources available in the country are rice husk, crop residue, wood, jute stick, animal waste, municipal waste, sugarcane bagasse etc. Biogas mainly from animal and municipal wastes may be one of the potential renewable energy resources for Bangladesh. Presently, there are tens of thousands of households and village-level biogas plants in place throughout the country. It is a potential source to harness basic biogas technology for cooking, and rural and periurban electrification to provide electricity during periods of power shortfalls ${ }^{28}$.

However, the REP also suggests forming Sustainable
Energy Development Agency (SEDA) as a focal point for sustainable energy development and promotion, 'sustainable energy' comprising renewable energy and energy efficiency. Moreover, the policy proposes to give subsidy and tax incentive to attract investors to this industry so that it can be flourished properly.

\section{The Nuclear Power Plant Act}

Nuclear power is considered to be one of the cheapest and reliable sources of electricity internationally and virtually it is environment friendly because it emits no greenhouse gases. However, as Bangladesh has diverted it focus to renewable and environmentally friendly energy production, hence, it introduced a giant project with Russia to establish a nuclear power plant at Rooppur which is popularly known as Rooppur Nuclear Power Plant (RNPP) is country's first planned 2.4 GWe nuclear power plant ${ }^{29}$. The government has formed an authority under the Nuclear Power Plant Act, 2015 for oversee the building process of the RNPP.

However, after the disastrous nuclear accident at Fukushima, Japan in 2011, many countries, particularly in Europe, decided to phase out nuclear power plants. Russia, China and India, on the other hand, continued with nuclear power but incorporated new safety features in the designs that increased the cost of the power plants significantly ${ }^{30}$.

Every nuclear power plant needs to be supported by the required infrastructure e.g. legal and regulatory framework, management plan, technological requirements, safety, finance and human resource development etc. To ensure all these, Bangladesh has adopted the International Atomic Energy Agency (IAEA) Milestones guidelines. It has been made compulsory to follow codes, guides and standards of IAEA in designing, commissioning and operation \& maintenance of the $\mathrm{RNPP}^{31}$.

Despite that, there is huge debate between the civil society and the government about the safety issues of the project. The government has ensured that they put greater emphasis on the site safety aspects and engineering solutions to increase resistance of plants to extreme events and cliff edge effects and five layers of safety barriers would be put in place. The nuclear power plant units have been designed by adopting sitespecific safety measures. The design basis for natural and human-induced external events such as earthquakes, floods, aircraft crash, explosions, etc, and the radiological impact on the population and on the territory during both normal and accidental conditions have already been analyzed and defined ${ }^{32}$.

The technical provisions for the safety measures (both active and passive system) have been implemented in the design of the plants to meet the acceptance criteria 
established for design extension conditions. These provisions will ensure back-up for all safety functions needed to prevent the occurrence of beyond-design-basis accidents. Another safety concern is the management of nuclear waste, particularly spent fuel of nuclear power plant. The government has recently signed an agreement with Russia under which spent fuel of the RNPP will be returned to Russia ${ }^{33}$.

\section{The Atomic Energy Control Act}

Section 11 of the Atomic Energy Control Act, 2012 specifies the functions of the authority constituted under the Act to monitor, supervise and control activities relating to atomic energy. According to the mentioned section, the concerned authority will oversee the safety measures relating to atomic energy including health and environmental security in the country. Chapter five of the law deals with the waste management and safety particularly. The mentioned Act obliged main producer to deal with safe management of radioactive wastages from production to disposal ${ }^{34}$. Subsequently, Chapter Six deals with emergency precaution and preventive measures in both on site and off site emergency plan. In addition, Chapter Eight arranges mechanism for regular inspection and action.

\section{The Electricity Act}

The newly enacted Electricity Act, 2012 of Bangladesh is mainly dealing with the supply and management of energy inside the country. However, it also authorizes public private partnership to install new power project and licensing system of establish new power plant. Despite that, the Electricity Act, 2012 provides provision for encouragement and of power generation utilizing renewable and non-conventional energy ${ }^{35}$.

\section{Conclusion}

Power and energy are the main driving force of country's economy and prerequisite for development. There is enormous demand of electricity, oil, gas and natural resources in agriculture, industry, service sector as well as daily life of Bangladesh. In this context, the government has given top priority to the development of power and energy sector. Nevertheless, that development must be ensured by taking care of climate change mitigation and affordability of energy. In order to do it, this is high time to concentrate on renewable energies mainly. However, being a currency importing (developing) country, it faces challenges in order to maintain an efficient energy triangle system. Despite that, the country's legislations and policies clearly show its commitment towards ensuring energy triangle. Although it is evident from the above discussion that there are deficiencies in those laws and policies which can be overcome by government's willingness to take further initiatives in this regard. Bringing necessary amendments and effective implementation of those policies and laws can bring visible change to the scenario of our energy sector.
Hence, the State can take opportunity to reaffirm its position towards environmentally friendly affordable energy by amending those policies and legislations.

Md. Raisul Islam Sourav is a Chevening Scholar 2017-18 and currently pursuing his second LLM in International Energy Law and Policy at the University of Stirling, UK. Prior to this he was working as an Assistant Professor and Coordinator, Department of Law, Dhaka International University (DIU), Dhaka, Bangladesh (presently on study leave) and an Advocate of the Supreme Court in Bangladesh. He achieved his LL.B (Hons) \& first LL.M degree from Northern University Bangladesh (NUB) with distinction. He is also a regular contributor to renown national daily newspapers of Bangladesh; Law and Justice Analyst; Essayist; Researcher and, Equality and Rights Activist. He has recently presented a paper titled "Modern Sources of Law: A South Asian Perspective" at the Regional Conference on International Law and Dynamic Asia, organized by the Asian Society of International Law (Asian SIL) on 13-15 May 2016 in Hanoi, Vietnam.

\section{Corresponding E-mail: sourav.mollick@gmail.com}

\section{Footnotes}

1. Vermont Law School Library, "Energy Law and Policy Research: Introduction" < http://libguides. vermontlaw.edu/EnergyLawResources $>$ accessed on 3 November 2017

2. R J Heffron, Energy Law: An Introduction [2015] Springer Briefs in Law

3. R J Heffron and K Talus, "The Development of Energy Law in 21st Century: A Paradigm Shift" [2016] Journal of World Energy Law and Business, 9, 189-202

4. James Simpson and Kieran McNamara, "Elements of Energy Policy”, Global Energy Dialogue, Country Studies Division” 2011 International Energy Agency

5. R J Heffron, Energy Law: An Introduction [2015] Springer Briefs in Law.

6. World Energy Council and Oliver Wyman, "World Energy Trilemma: Defining Measures to Accelerate the Energy Transition"

7. James Simpson and Kieran McNamara, "Elements of Energy Policy”, Global Energy Dialogue, Country Studies Division" 2011 International Energy Agency

8. Section 2(b) of the Energy Regulatory Commission Act, 2003

9. H Gunatilake and D Roland-Holst, "Energy Policy Options for sustainable Development of Bangladesh" [November 2013] DB Economics Working Paper Series No. 359 
10. Raisul Islam Sourav, "Balancing the Energy Trilemma" [24 October 2017] The Daily Star < http://www.thedailystar.net/law-our-rights/ balancing-the-energy-trilemma-1480987 $>$ accessed on 5 November 2017

11. Neil Gunningham, "Managing the Energy Trilemma: The Case of Indonesia" [2013] Energy Policy 54, 184-193

12. Raisul Islam Sourav, "Balancing the Energy Trilemma" [24 October 2017] The Daily Star < http://www.thedailystar.net/law-our-rights/ balancing-the-energy-trilemma-1480987> accessed on 5 November 2017

13. Raisul Islam Sourav, "Balancing the Energy Trilemma" [24 October 2017] The Daily Star < http://www.thedailystar.net/law-our-rights/ balancing-the-energy-trilemma-1480987> accessed on 5 November 2017

14. ibid

15. Raisul Islam Sourav, "Is Universal Access to Energy a Human Right in Bangladesh?” [11 December 2017] The Daily Observer < http://www.observerbd.com/ details.php?id=110514> accessed on 4 January 2018

16. Raisul Islam Sourav, "There's no Progress without Energy" [12 December 2017] The Daily Dhaka Tribune <http://www.dhakatribune.com/opinion/ op-ed/2017/12/12/theres-no-progress-withoutenergy/> accessed on 4 January 2018

17. S Islam and M Z R Khan, 'A Review of energy Sector of Bangladesh" [2017] Energy Procedia 110, 611-618

18. The National Energy Policy 1995

19. The National Energy Policy 2005

20.Presentation on "Energy Scenario: Bangladesh"<http://eneken.ieej.or.jp/data/3113. pdf $>$ accessed 4 November 2017

21. ibid

22. F Ahmed, A Q A Amin M Hasanuzzaman and $\mathrm{R}$ Saidur, "Alternative Energy Resources in Bangladesh and Future Prospect" [2013] Renewable and Sustainable Energy Reviews 25, 698-707

23.ibid

24. The Renewable Energy Policy, 2008

25. Article 16 of the Constitution of the People's Republic of Bangladesh

26. The Renewable Energy Policy, 2008

27. ibid

28. The Renewable Energy Policy, 2008

29. See details at http://www.rooppurnpp.gov.bd accessed on 4 November 2017

30.Shamusdozza Sajen, "All You Need to Know about Rooppur Nuclear Power Programme", 16 October 2017, The Daily Star, http://www.thedailystar.net/ supplements/rooppur-nuclear-power-programme/ all-you-need-know-about-rooppur-nuclear-powerprogramme accessed on 5 November 2017

31. Shamusdozza Sajen, "All You Need to Know about Rooppur Nuclear Power Programme", 16 October 2017, The Daily Star, http://www.thedailystar.net/ supplements/rooppur-nuclear-power-programme/ all-you-need-know-about-rooppur-nuclear-powerprogramme accessed on 5 November 2017

32. Shamusdozza Sajen, "All You Need to Know about Rooppur Nuclear Power Programme”, 16 October 2017, The Daily Star, http://www.thedailystar.net/ supplements/rooppur-nuclear-power-programme/ all-you-need-know-about-rooppur-nuclear-powerprogramme accessed on 5 November 2017

33.ibid

34. Section 38 of the Atomic Energy Control Act, 2012

35. Section $5 \mathrm{~A}$ of the Electricity Act, 2012

\section{Bibliography}

\section{A. Legislations}

i) The Atomic Energy Control Act, 2012

ii) The Constitution of the People's republic of Bangladesh

iii) The Electricity Act, 2012

iv) The Energy Regulatory Commission Act, 2003

v) The Nuclear Power Plant Act, 2015

\section{B. Policies}

i) The National Energy Policy 2005

ii) The Renewable Energy Policy 2008

\section{Journal Articles}

i) Ahmed, F, Amin, A Q A, Hasanuzzaman, M and Saidur, R, "Alternative Energy Resources in Bangladesh and Future Prospect" [2013] Renewable and Sustainable Energy Reviews 25, 698-707

ii) Gunningham, Neil, "Managing the Energy Trilemma: The Case of Indonesia" [2013] Energy Policy 54, 184-193

iii) Islam, $S$ and Khan, $M Z R$, 'A Review of energy Sector of Bangladesh" [2017] Energy Procedia 110, 611-618

iv) Heffron, R J, "Energy Law: An Introduction" [2015] Springer Briefs in Law

v) Heffron, R J and Talus, K, 'The Development of Energy Law in 21st Century: A Paradigm Shift" [2016] Journal of World Energy Law and Business, 9, 189-202

\section{Institutional Documents}

i) Gunatilake, $\mathrm{H}$ and Roland-Holst, D "Energy Policy Options for sustainable Development of Bangladesh" [November 2013] DB Economics Working Paper Series No. 359

ii) Simpson, James and McNamara, Kieran, "Elements 
of Energy Policy”, Global Energy Dialogue, Country Studies Division" 2011 International Energy Agency

iii) World Energy Council and Oliver Wyman, "World Energy Trilemma: Defining Measures to Accelerate the Energy Transition"

\section{E. Online Documents}

i) Presentation on "Energy Scenario: Bangladesh" <http://eneken.ieej.or.jp/data/3113.pdf> accessed 4 November 2017

ii) Sajen, Shamusdozza, All You Need to Know about Rooppur Nuclear Power Programme, 16 October 2017, The Daily Star, <http://www.thedailystar.net/ supplements/rooppur-nuclear-power-programme/ all-you-need-know-about-rooppur-nuclear-powerprogramme $>$ accessed 5 November

iii) See details at http://www.rooppurnpp.gov.bd accessed on 4 November 2017 iv) Sourav, Raisul Islam, "Balancing the Energy Trilemma” [24 October 2017] The Daily Star < http://www.thedailystar.net/law-our-rights/ balancing-the-energy-trilemma-1480987> accessed on 5 November 2017

v) Sourav, Raisul Islam, "Is Universal Access to Energy a Human Right in Bangladesh?” [11 December 2017] The Daily Observer < http://www.observerbd.com/ details.php?id=110514> accessed on 4 January 2018

vi) Sourav, Raisul Islam, "There's no Progress without Energy" [12 December 2017] The Daily Dhaka Tribune < http://www.dhakatribune.com/opinion/ op-ed/2017/12/12/theres-no-progress-withoutenergy/> accessed on 4 January 2018

vii)Vermont Law School Library, "Energy Law and Policy Research: Introduction" <http://libguides. vermontlaw.edu/EnergyLawResources $>$ accessed 3 November 2017 